\title{
Fluorometric Deoxyribonucleic Acid-Deoxyribonucleic Acid Hybridization in Microdilution Wells as an Alternative to Membrane Filter Hybridization in which Radioisotopes Are Used To Determine Genetic Relatedness among Bacterial Strains
}

\author{
TAKAYUKI EZAKI, ${ }^{*}$ YASUHIRO HASHIMOTO, AND EIKO YABUUCHI \\ Department of Microbiology, School of Medicine, Gifu University, 40 Tsukasa-machi, Gifu, 500 Japan
}

\begin{abstract}
Fluorometric hybridization in microdilution wells was developed to determine genetic relatedness among microorganisms. Total chromosomal deoxyribonucleic acid (DNA) for hybridization reactions was labeled with photoreactive biotin (photobiotin). The biotinylated DNA was hybridized with single-stranded unlabeled DNAs which had been immobilized on the surfaces of microdilution wells. After hybridization, biotinylated DNA was quantitatively detected with beta-D-galactosidase and a fluorogenic substrate, 4-methylumbelliferyl-betaD-galactopyranoside. Homology values obtained with this fluorometric direct binding method were compared with values obtained with two membrane filter methods, one in which photobiotin labeling was used and one in which radioisotope labeling was used. The results showed that the fluorometric direct binding method in which microdilution wells are used could be an alternative to radioisotope and membrane filter hybridization methods.
\end{abstract}

Quantitative measurement of deoxyribonucleic acid (DNA)-DNA hybridization from renaturation rates has contributed to determinations of genetic relatedness among bacterial strains $(2,4,5,13,19)$. The methods usually used in this technique are either a free solution method in which S1 nuclease, (4), spectrophotometry, $(5,19)$, or hydroxyapatite is used (2) or a method in which single-stranded DNA is fixed on a solid support, such as nitrocellulose filters $(1,12)$. However, to carry out most of these hybridization experiments, DNA must be labeled with radioactive substances by nick translation (18) or random primed labeling (9).

Recent developments have made it possible to label DNA with nonradioactive materials without using enzymes $(10$, $11,17)$. Biotinylation of DNA with photoreactive biotin (photobiotin) (10) is one of these recent developments. In this procedure DNA is labeled by mixing it with photobiotin and irradiating the mixture with sunlight for $15 \mathrm{~min}$. Biotinylated DNA has been used for Southern and dot blot hybridizations $(10,14)$. Hybridized DNA fragments are usually visualized with alkaline phosphatase or peroxidase color detection methods $(10,14,17)$. We used photobiotinylated DNA for quantitative detection of DNA-DNA hybridization to determine genetic relatedness among microorganism for taxonomic studies $(4,5,19)$. Quantitative hybridization was carried out in microdilution wells. After hybridization, streptavidin-conjugated beta-D-galactosidase was bound to photobiotinylated DNA. A sensitive fluorogenic substance, 4-methylumbelliferyl-beta-D-galactopyranoside was used as a substrate (16). In this paper the fluorometric hybridization method is compared with a radioisotope method (19) as an alternative procedure to determine genetic relatedness among bacteria.

\section{MATERIALS AND METHODS}

DNAs of bacterial strains (Table 1) were prepared by the procedures of Marmur, with minor modifications (8). Under optimal conditions, $100-\mu$ l portions of a heat-denatured, purified reference DNA solution ( $20 \mu \mathrm{g}$ of DNA per $\mathrm{ml}$ ) in

\footnotetext{
* Corresponding author
}

phosphate-buffered saline (PBS; $8 \mathrm{mM} \mathrm{Na} \mathrm{HPO}_{4}, 1.5 \mathrm{mM}$ $\mathrm{KH}_{2} \mathrm{PO}_{4}, \mathrm{pH} 7.2,137 \mathrm{mM} \mathrm{NaCl}, 2.7 \mathrm{mM} \mathrm{KCl}$ ) containing 0.1 $\mathrm{M} \mathrm{MgCl}{ }_{2}$ were incubated for $1 \mathrm{~h}$ at $37^{\circ} \mathrm{C}$ in microdilution plates (MicroFluor type B plates; Dynatech Laboratories, Inc., Alexandria, Va.). Each solution was then aspirated with an automatic microplate washer (model AMW2 AutoMini-Washer; Bio-Tec Corp., Ltd., Tokyo, Japan). The microdilution plates were washed once with PBS containing $0.1 \mathrm{M} \mathrm{MgCl}_{2}$ and then dried at $60^{\circ} \mathrm{C}$ overnight.

Photobiotinylation of DNA was performed as described previously (7). Briefly, $5 \mu \mathrm{l}$ of photobiotin (Vector Laboratories, Inc., Burlingame, Calif.) and an equal volume of a denatured DNA solution ( $5 \mu \mathrm{g}$ of DNA in distilled water) were mixed in an Eppendorf tube and then irradiated with a sunlamp $(500 \mathrm{~W})$ for $15 \mathrm{~min}$. After irradiation, free photobiotin was removed by 2-butanol extraction. The biotinylated DNA was used immediately for hybridization experiments.

For quantitative detection of biotinylated DNA in microdilution wells, $200-\mu l$ portions of a prehybridization solution $(2 \times \mathrm{SSC}[1 \times \mathrm{SSC}$ is $0.15 \mathrm{M} \mathrm{NaCl}$ plus $0.015 \mathrm{M}$ sodium citrate], $5 \times$ Denhardt solution, $50 \%$ formamide) containing $200 \mu \mathrm{g}$ of denatured salmon sperm DNA per ml were added to microdilution wells which had been coated with reference DNAs or which contained small filters coated with reference DNAs. The microdilution plates were then incubated at $37^{\circ} \mathrm{C}$ for $1 \mathrm{~h}$. The prehybridization solution was then removed from the wells with the Auto-Mini-Washer and replaced with $100-\mu$ l portions of hybridization mixture $(2 \times$ SSC, $5 \times$ Denhardt solution, $3 \%$ dextran sulfate, $50 \%$ formamide, $50 \mu \mathrm{g}$ of denatured salmon DNA per $\mathrm{ml}$ ) containing $50 \mathrm{ng}$ of biotinylated DNA. The microplates were then covered with vinyl tape, and hybridization experiments were carried out at a low temperature to minimize the evaporation of the hybridization mixture. Although $25^{\circ} \mathrm{C}$ lower than the thermal denaturation temperature $\left(T_{m}\right)$ in $2 \times \mathrm{SSC}$ buffer is generally accepted as an optimal temperature for hybridization, we selected $55^{\circ} \mathrm{C}$ lower than the $T_{m}$ for quantitative hybridization because our hybridization mixture contained $50 \%$ formamide and the hybridization temperature could be brought down to a temperature $55^{\circ} \mathrm{C}$ lower than the $T_{m}(15)$. 
TABLE 1. Bacterial strains

\begin{tabular}{|c|c|}
\hline Strain & Remarks \\
\hline \multicolumn{2}{|c|}{ Escherichia coli $\mathrm{K}-12 \ldots \ldots \ldots \ldots \ldots \ldots \ldots$} \\
\hline \multicolumn{2}{|l|}{$\begin{array}{l}\text { Streptococcus anginosus } \\
\text { NCTC } 10713^{\mathrm{T}}\end{array}$} \\
\hline \multicolumn{2}{|l|}{ Streptococcus anginosus } \\
\hline $\begin{array}{l}\text { Streptococcus anginosus } \\
\text { ATCC } 27335 \text {.............. }\end{array}$ & $\begin{array}{l}\text { Human clinical isolate } \\
\text { Previously called Streptococ- }\end{array}$ \\
\hline $\begin{array}{l}\text { Streptococcus anginosus } \\
\text { ATCC } 27823 \text {....................... }\end{array}$ & $\begin{array}{l}\text { Previously called Streptococ- } \\
\text {.. cus constellatus }{ }^{a}\end{array}$ \\
\hline Streptococcus pyogenes & Type strain \\
\hline Streptococcus agalactiae & Type strain \\
\hline \multicolumn{2}{|l|}{$\begin{array}{l}\text { ATCC } 33152^{\mathrm{T}} \ldots \ldots \ldots \ldots . . . . \\
\text { Legionella bozemanü }\end{array}$} \\
\hline \multicolumn{2}{|l|}{ Legionella bozemanii } \\
\hline \multicolumn{2}{|l|}{$\begin{array}{l}\text { Legionena partstensis } \\
\text { ATCC } 35299^{\mathrm{T}} \ldots . . . . . .\end{array}$} \\
\hline \multicolumn{2}{|l|}{ Legionella feeleii } \\
\hline Legionella rublilucens & Type strain \\
\hline ATCC $35304^{\mathrm{T}} \ldots \ldots \ldots$ & Type strain \\
\hline $\begin{array}{l}\text { Legionella erythra } \\
\quad \text { ATCC } 35303^{\mathrm{T}} \ldots \ldots \ldots . .\end{array}$ & Type strain \\
\hline $\begin{array}{l}\text { Legionella cherii } \\
\quad \text { ATCC } 35252^{\mathrm{T}} \ldots \ldots \ldots \ldots \ldots\end{array}$ & \\
\hline $\begin{array}{l}\text { ATCC } 35252^{\mathrm{T}} \ldots \ldots \ldots \ldots \ldots \\
\text { Legionella jamestownensis }\end{array}$ & Type strain \\
\hline $\begin{array}{l}\text { Legionella micdadei } \\
\quad \text { ATCC } 33218^{\mathrm{T}} \ldots \ldots \ldots \ldots . . .\end{array}$ & Type strain \\
\hline $\begin{array}{l}\text { Legionella gormanii } \\
\quad \text { ATCC } 33297^{\mathrm{T}} \ldots \ldots \ldots \ldots . . . . . . .\end{array}$ & Type strain \\
\hline $\begin{array}{l}\text { ATCC } 33297^{\mathrm{T}} \text {............... } \\
\text { Pseudomonas aeruginosa }\end{array}$ & Type strain $\left(=\right.$ ATCC $\left.10145^{\mathrm{T}}\right)$ \\
\hline $\begin{array}{l}\text { Pseudomonas cepacia } \\
\text { GIFU } 645^{\mathrm{T}} \ldots \ldots \ldots \ldots \ldots . . . . . . .\end{array}$ & Type strain $\left(=\right.$ ATCC $\left.25416^{\mathrm{T}}\right)$ \\
\hline Pseudomonas diminuta & Type strain $\left(=\right.$ ATCC $\left.11568^{\mathrm{T}}\right)$ \\
\hline Pseudomonas paucimobilis & Type strain $\left(=\right.$ ATCC $\left.29837^{\mathrm{T}}\right)$ \\
\hline $\begin{array}{r}\text { Pseudomonas pseudoalcali } \\
\text { GIFU } 363^{\mathrm{T}} \ldots \ldots \ldots \ldots \ldots \ldots \ldots . . . . . . .\end{array}$ & Type strain $\left(=\right.$ ATCC $\left.17440^{\mathrm{T}}\right)$ \\
\hline $\begin{array}{l}\text { Pseudomonas mendocina } \\
\text { GIFU } 1953^{\mathrm{T}} \ldots \ldots \ldots \ldots \ldots . . . . .\end{array}$ & Type strain $\left(=\right.$ ATCC $\left.25411^{\mathrm{T}}\right)$ \\
\hline 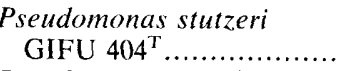 & Type strain $\left(=\right.$ ATCC $\left.17588^{\mathrm{T}}\right)$ \\
\hline $\begin{array}{l}\text { Pseudomonas putida } \\
\text { GIFU } 1081^{\mathrm{T}} \ldots \ldots \ldots \ldots \ldots .\end{array}$ & Type strain $\left(=\right.$ ATCC $\left.12633^{\mathrm{T}}\right)$ \\
\hline $\begin{array}{l}\text { Pseudomonas fluorescens } \\
\text { ATCC } 13523^{\mathrm{T}} \ldots \ldots \ldots \ldots \ldots . . . . .\end{array}$ & Type strain \\
\hline $\begin{array}{l}\text { Pseudomonas vesicularis } \\
\text { GIFU } 2388^{\mathrm{T}} \ldots \ldots \ldots \ldots \ldots . . . . . .\end{array}$ & Type strain $\left(=\right.$ ATCC $\left.11426^{\mathrm{T}}\right)$ \\
\hline
\end{tabular}

${ }^{a}$ See reference 3 .

After hybridization, the microdilution wells were washed four times with $300 \mu \mathrm{l}$ of $2 \times$ SSC buffer. A $100-\mu l$ portion of a streptavidin-beta-D-galactosidase (ZYMED Laboratories, Inc., San Francisco, Calif.) solution (10 ng/ml in PBS containing $0.5 \%$ bovine serum albumin and $0.1 \%$ Triton X-100) was added to the wells, and the preparations were incubated at $37^{\circ} \mathrm{C}$ for $30 \mathrm{~min}$. After incubation, the wells were washed twice with PBS containing $0.1 \%$ Triton X-100.

A $100-\mu l$ portion of $3 \times 10^{-4} \mathrm{M} 4$-methylumbelliferylbeta-D-galactopyranoside (Koch-light, Ltd., Suffolk, England) in PBS was added, and the plates were incubated at $37^{\circ} \mathrm{C}$ for several periods of time. The fluorescence intensity was measured with a MicroFluor reader (Dynatech Laboratories, Inc., Alexandria, Va.) at a wavelength of $360 \mathrm{~nm}$ for excitation and $450 \mathrm{~nm}$ for emission.

Preparation of DNA bound to nitrocellulose filters for membrane filter hybridization. A $250-\mu \mathrm{g}$ portion of purified, single-stranded DNA was suspended in $100 \mathrm{ml}$ of $2 \times \mathrm{SSC}$ buffer and passed through a nitrocellulose filter (type HAHY; diameter, $4.7 \mathrm{~cm}$; Nippon Millipore Corp., Yonezawa, Japan). The filter was dried at $42^{\circ} \mathrm{C}$ for $1 \mathrm{~h}$ and then punched out into small disks (diameter, $0.5 \mathrm{~cm}$ ). The filters were then baked at $80^{\circ} \mathrm{C}$ for $2 \mathrm{~h}$ and kept in a desiccator at room temperature. The filters were placed in a tissue culture plate with 48 wells (Costar, Cambridge, Mass.). Prehybridization and hybridization were carried out as described above. After hybridization, the filters were washed twice with $500 \mu \mathrm{l}$ of $2 \times \mathrm{SSC}$ containing $0.1 \%$ sodium dodecyl sulfate (SDS) for $15 \mathrm{~min}$ and twice with $500 \mu \mathrm{l}$ of $0.2 \times$ SSC containing $0.1 \%$ SDS for $15 \mathrm{~min}$. When ${ }^{32} \mathrm{P}$-labeled DNA was used, the hybridized filters were subjected directly to scintillation counting. When photobiotinylated DNA was used, the filters were placed in new Costar wells, and $200 \mu \mathrm{l}$ of PBS supplemented with $2 \%$ bovine serum albumin (fraction V; Sigma Chemical Co., St. Louis, Mo.) and $0.1 \%$ Triton X-100 was added. The Costar plates were incubated at $37^{\circ} \mathrm{C}$ for $30 \mathrm{~min}$, after which $2 \mathrm{ng}$ of streptavidin-betaD-galactosidase was added to each well. After 30 min of incubation at room temperature, the solution was discarded, and wells with filters were washed three times with $1 \mathrm{ml}$ of PBS containing $0.1 \%$ Triton $X-100$. The filters were then transferred to microdilution wells, and $100 \mu \mathrm{l}$ of a 4-methylumbelliferyl-beta-D-galactoside solution was added to each well. Fluorescence intensity was determined as described above.

\section{RESULTS}

Immobilization of DNAs in microdilution wells. Optimal conditions to adsorb single-stranded DNA to microdilution wells were studied by changing the compositions and concentrations of buffer. Single-stranded DNA of Escherichia coli K-12 was well adsorbed to a microdilution well when it was dissolved in PBS supplemented with $0.1 \mathrm{M} \mathrm{MgCl}_{2}$. The incubation time for optimal DNA adsorption depended on the concentration of DNA (Fig. 1). When less than $500 \mathrm{ng}$ of DNA was added to a microdilution well, maximum adsorption was obtained after overnight incubation. With 1 or $2 \mu \mathrm{g}$ of DNA, adsorption maxima were observed within $1 \mathrm{~h}$. The maximum amount of DNA adsorbed to each well was calculated to be $300 \mathrm{ng}$ by measuring the supernatant recovered from each well.

To study the stability of the DNA immobilized in microdilution wells, biotinylated DNA was fixed in microdilution wells, and the remaining DNA was determined after washing with three different washing solutions (Fig. 2). When a microplate before drying was washed with $2 \times$ SSC containing $0.1 \%$ SDS, about $40 \%$ of the DNA was washed out after 40 washes. However, more than $90 \%$ of the DNA still remained after 40 washes with the same washing solution when a microplate was dried at $60^{\circ} \mathrm{C}$ overnight before washing. DNAs on dried microplates were also not washed out after 40 washes with PBS containing $0.1 \%$ Triton X-100.

Determination of the optimal dose of streptavidin-betaD-galactosidase. A linear relationship between the amount of beta-D-galactosidase and fluorescence intensity is shown in Fig. 3. When $10 \mathrm{nU}$ of beta-D-galactosidase was added to a microdilution well, the fluorescence intensity exceeded 


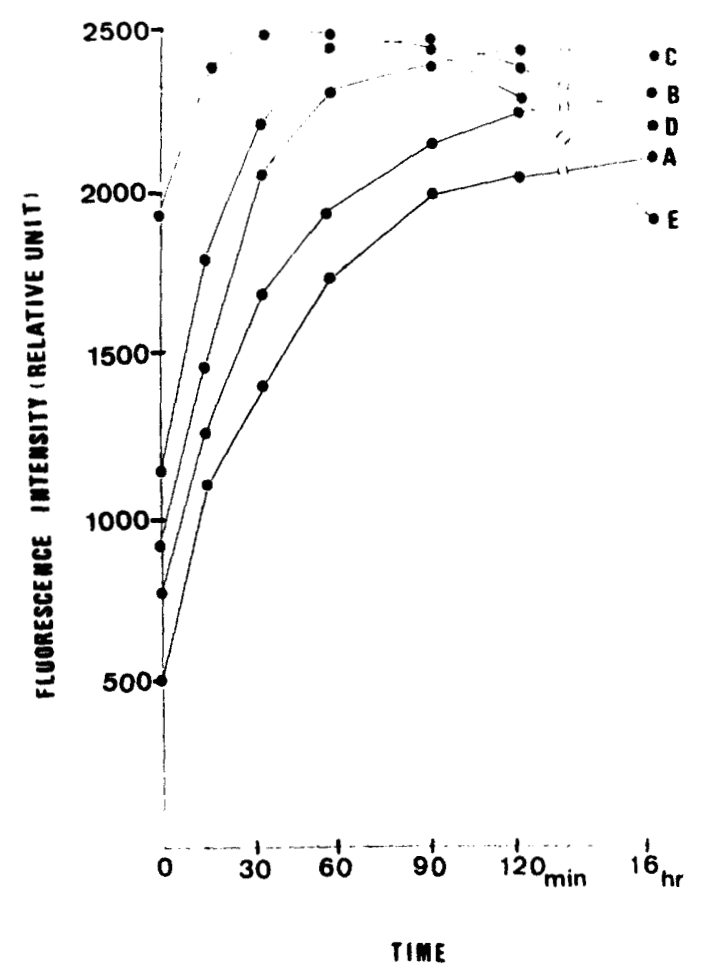

FIG. 1. Determination of the optimal dose and binding time for single-stranded DNA to be immobilized in microdilution wells. Biotinylated single-stranded DNA of E. coli K-12 was added to microdilution wells. Microdilution plates were incubated at $37^{\circ} \mathrm{C}$. DNA solutions were discarded after different incubation times and were washed once with PBS containing $0.1 \mathrm{M} \mathrm{MgCl}$. The plates were dried. The amount of immobilized photobiotin was determined by the method described in the text. The amounts of photobiotinylated DNA added to the microtiter wells were as follows: curve A, $0.1 \mu \mathrm{g}$; curve B, $0.2 \mu \mathrm{g}$; curve C, $0.5 \mu \mathrm{g}$; curve $\mathrm{D}, 1.0 \mu \mathrm{g}$; curve $\mathrm{E}$, $2.0 \mu \mathrm{g}$.

1,000 relative fluorencence counts within $10 \mathrm{~min}$. After hybridization, however, the fluorescence intensity of homologous wells reached 1,000 counts within 30 to $120 \mathrm{~min}$. According to the results of preliminary experiments (Fig. 3), this means that approximately 0.1 to $1 \mathrm{nU}$ of streptavidinbeta-D-galactosidase was bound to biotinylated DNA. Thus, we usually added $10 \mathrm{nU}$ of streptavidin-beta-D-galactosidase to each hybridization well and stopped the enzyme reaction when the fluorescence count reached 1,000 counts.

Determination of optimal incubation time to determine homology values. After the fluorogenic substrate was added, homology values were determined after different incubation times (Fig. 4). The homology values of several streptococci against Streptococcus anginosus NCTC $10713^{\mathrm{T}}(\mathrm{T}=$ type strain) remained nearly identical between 30 and 120 min after substrate was added. The absolute fluorescence intensity of the well with DNA from the labeled strain reached a maximum level of about 4,300 counts.

Hybridization time and temperature. Three hybridization temperatures $\left(37,45\right.$, and $\left.50^{\circ} \mathrm{C}\right)$ were selected for Legionella pneumophila ATCC $33152^{\mathrm{T}}$, which had a low guanineplus-cytosine $(G+C)$ content $(G+C$ content of the DNA, 39 mol\%, as determined by the $T_{m}$ method), and three temperatures $\left(42,50\right.$, and $\left.55^{\circ} \mathrm{C}\right)$ were selected for Pseudomonas aeruginosa ATCC $10145^{\mathrm{T}}(\mathrm{G}+\mathrm{C}$ content of the DNA, 66 mol\%, as determined by the $T_{m}$ method). Each DNA was

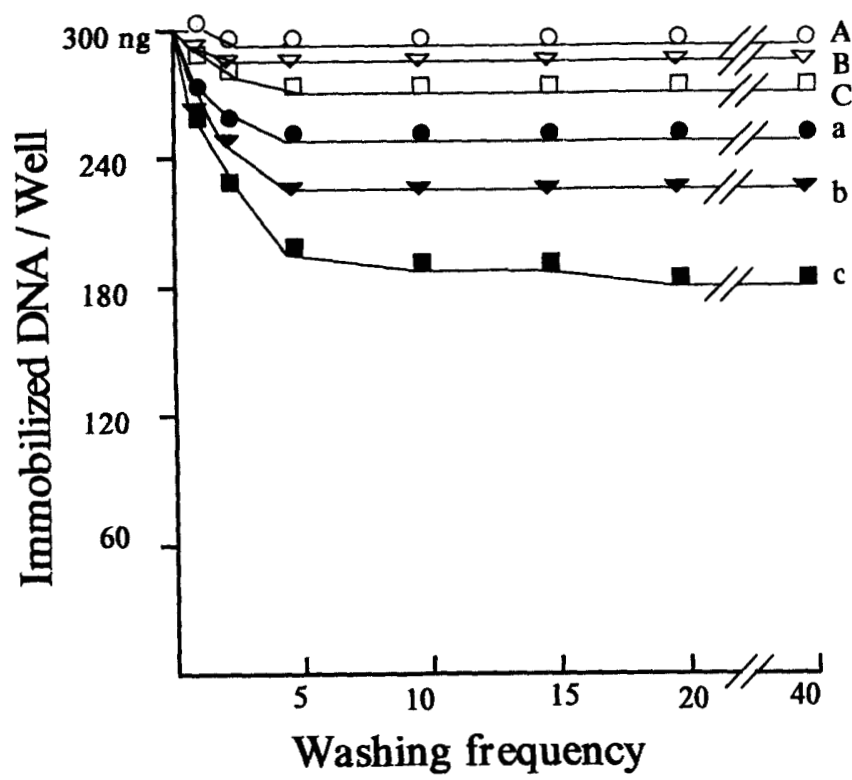

FIG. 2. Residual DNA immobilized in microdilution wells after washing with three different washing solutions. Curves $A$ and a, $2 \times$ SSC; curves B and b, $0.1 \%$ SDS in $2 \times$ SSC; curves C and $c, 0.1 \%$ Triton X-100 in PBS. For curves $a, b$, and $c$ the microplates were washed without drying. For curves $a, b$, and $c$ the microplates were washed after drying at $60^{\circ} \mathrm{C}$ overnight.

Iabeled with photobiotin and hybridized with its own unlabeled DNA immobilized on the bottom of a microdilution well. Hybridization experiments were stopped after different incubation times, and the amounts of biotinylated DNAs

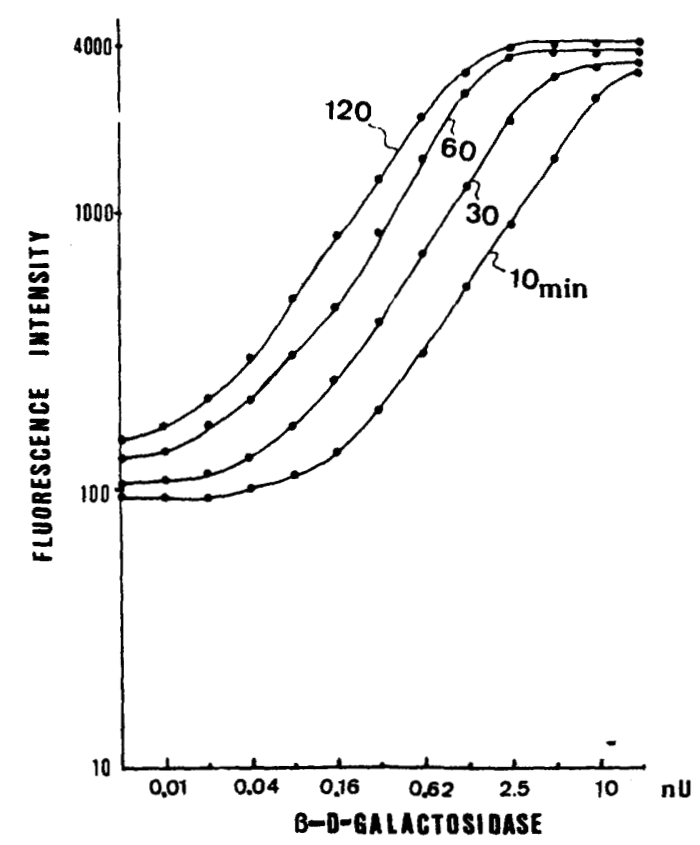

FIG. 3. Relationship between the amount of beta-D-galactosidase and fluorescence intensity. A $10-$ to $0.005-\mathrm{nU}$ portion of beta-D-galactosidase was added to each well. The fluorescence intensity was read at $10,30,60$, and 120 min after $100 \mu$ l of a 4-methylumbelliferyl-beta-D-galactopyranoside solution was added. 


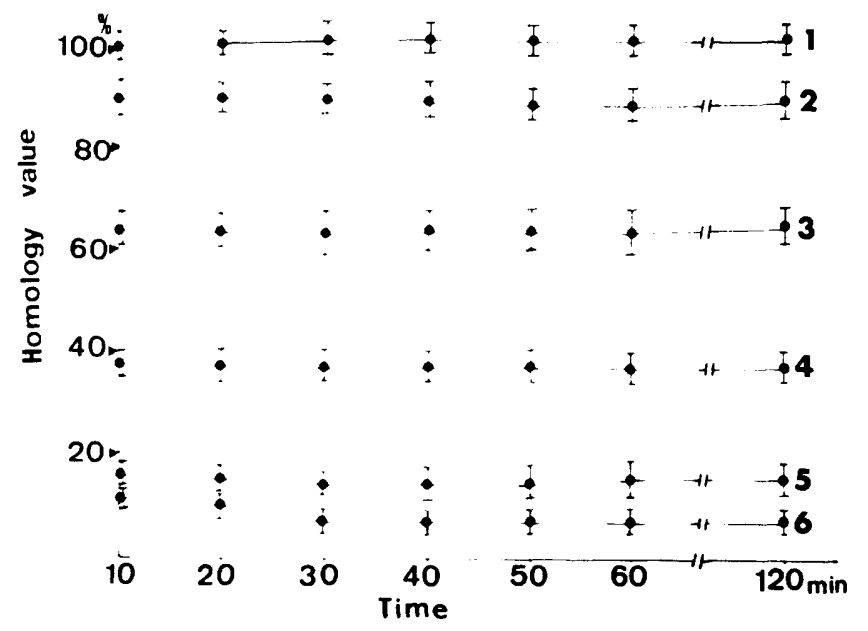

FIG. 4. Homology values determined at 10-min intervals after a substrate was added. S. anginosus NCTC $10713^{\mathrm{T}}$ DNA was labeled with photobiotin, and a DNA relatedness experiment was carried out with the following strains: S. anginosus NCTC $10713^{\mathrm{T}}$ (curve 1), S. anginosus GIFU 10035 (curve 2), S. anginosus NCTC 27823 (curve 3), S. pyogenes ATCC $12344^{\mathrm{T}}$ (curve 4 ), S. agalactiae NCTC $8181^{\mathrm{T}}$ (curve 5), and E. coli $\mathrm{K}-12$ (curve 6 ).

were measured (Fig. 5). When the fluorescence intensity after $24 \mathrm{~h}$ of hybridization was calculated as $100 \%$, about $20 \%$ of the biotinylated DNA hybridized within $2 \mathrm{~h}$ of hybridization at each optimal temperature (L. pneumophila at $37^{\circ} \mathrm{C}$ and $P$. aeruginosa at $42^{\circ} \mathrm{C}$ ).

Homology values for several streptococci calculated against $S$. anginosus NCTC $10713^{\mathrm{T}}$ were determined after 2 , 8 , and 24 h of hybridization at $37^{\circ} \mathrm{C}$ (Fig. 6). The homology values obtained from shorter hybridization times were slightly lower than those obtained from longer hybridization times, but the values were not significantly different.

Comparison with membrane filter methods. The homology values obtained by the fluorometric direct binding method were compared with the values obtained by membrane filter methods under optimal conditions (Fig. 7). The DNA of $S$. anginosus NCTC $10713^{\mathrm{T}}$ was labeled with ${ }^{32} \mathrm{P}$ by nick translation and was used for the membrane filter method. The same DNA was biotinylated by photobiotin and used both for the membrane filter method and the direct binding method. The homology values for streptococcal strains calculated against the type strain of $S$. anginosus, strain NCTC 10713, obtained with these three methods were very close to each other.

Identification of organisms by rapid hybridization. Microplate hybridization was used for the identification of gram-positive cocci (6) and gram-negative bacteria (Fig. 8). Hybridization was carried out for $2 \mathrm{~h}$ under stringent conditions. To identify members of the genus Legionella, we selected $45^{\circ} \mathrm{C}$ for the hybridization temperature, although the optimal temperature for these organisms was calculated to be 37 to $40^{\circ} \mathrm{C}$ because the $\mathrm{G}+\mathrm{C}$ contents of their DNAs ranged from 38 and $43 \mathrm{~mol} \%$. The $\mathrm{G}+\mathrm{C}$ contents of the DNAs of members of the genus Pseudomonas ranged from 58 to $71 \mathrm{~mol} \%$, and $50^{\circ} \mathrm{C}$ was selected for the hybridization temperature for these organisms. By using $2 \mathrm{~h}$ of hybridization under stringent conditions, all of the legionellae and pseudomonads in Table 1 could be differentiated. Examples of hybridization data for eight species of legionellae and pseudomonads are shown in Fig. 8.
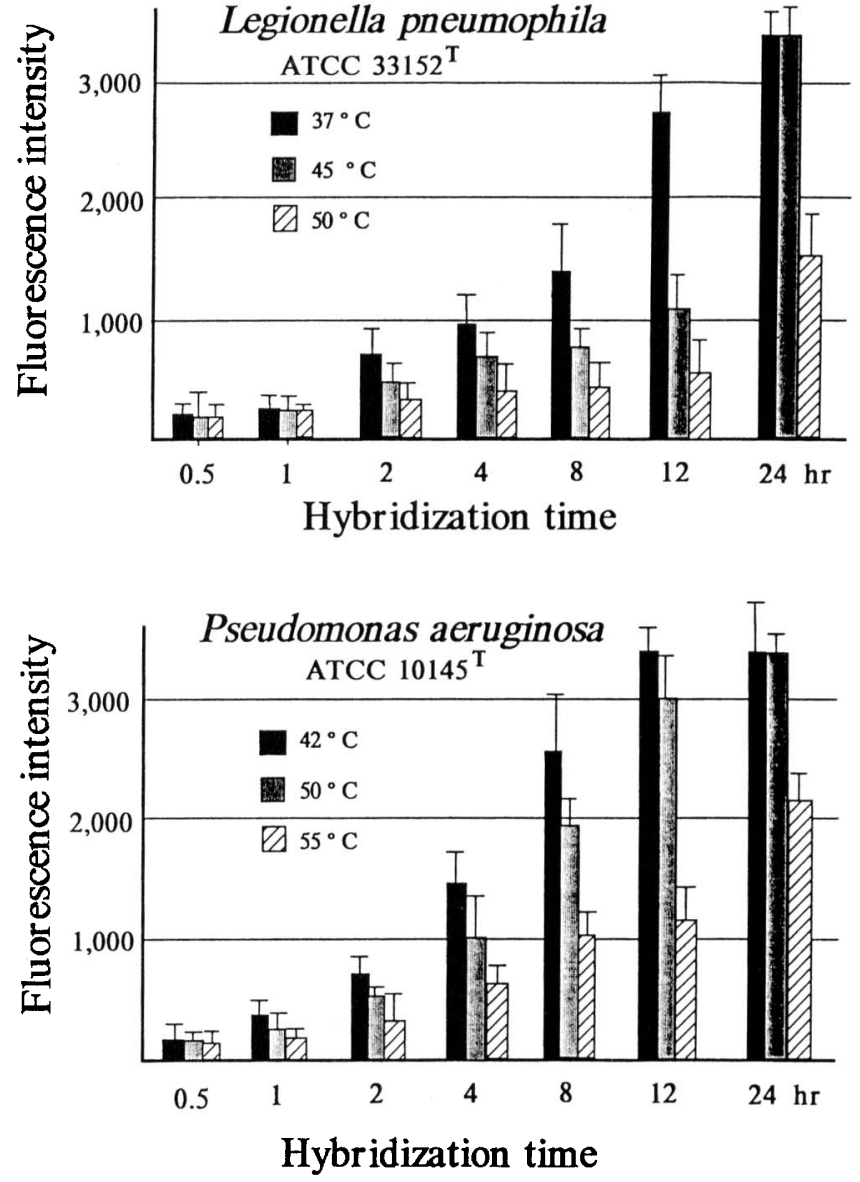

FIG. 5. Hybridization time and temperature. A 50-ng portion of labeled DNA was distributed into each well, where $300 \mathrm{ng}$ of unlabeled homologous DNA was immobilized. Hybridization experiments were carried out at different temperatures and for different times. The optimal hybridization temperature for $L$. pneumophila in the $2 \times$ SSC hybridization mixture containing $50 \%$ formamide was around $37^{\circ} \mathrm{C}$, and the temperature for $P$. aeruginos a was $42^{\circ} \mathrm{C}$. Two different higher temperatures were selected for stringent hybridization experiments for each organism. Incubation for the beta-Dgalactosidase reaction was stopped within 30 min after 4-methylumbelliferyl-beta-D-galactopyranoside was added.

\section{DISCUSSION}

In the early stages of our experiments, we expected that DNA immobilized in microdilution wells would be washed out by posthybridization washing. Indeed, $40 \%$ of the DNA immobilized in microdilution wells was washed out when a washing solution containing $0.1 \%$ SDS was used. Therefore, we removed SDS from our washing buffer when the direct binding method was used. Originally, we irradiated the microdilution plates with ultraviolet light to promote the immobilization of DNA. However, in preliminary experiments, the absolute fluorescence intensity of microtiter wells not irradiated with ultraviolet light was higher than the intensity of wells irradiated with ultraviolet light (data not shown). Therefore, ultraviolet irradiation was not used in succeeding work.

The values obtained from both membrane filter methods corresponded well to the values obtained from the direct binding microdilution method. However, the background for the membrane filter method in which photobiotin was used was higher than the background for the fluorometric direct binding method. 


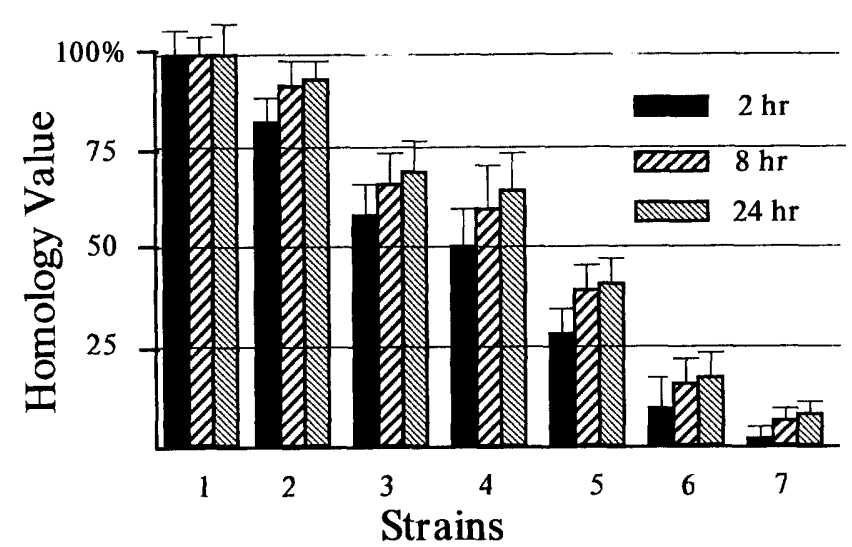

FIG. 6. Homology values for six selected strains of streptococci against $S$. anginosus NCTC $10713^{\mathrm{T}}$, calculated after 2,8 , and $24 \mathrm{~h}$ of hybridization. Hybridization experiments were carried out at $37^{\circ} \mathrm{C}$ in $2 \times$ SSC hybridization mixture containing $50 \%$ formamide. The bars at the tops of the columns indicate standard deviations. The average homology values were determined after six experiments. Unlabeled competitive DNAs were from $S$. anginosus NCTC $10713^{\mathrm{T}}$ (strain 1), S. anginosus GIFU 10035 (strain 2), S. anginosus ATCC 27335 (strain 3), S. anginosus ATCC 27823 (strain 4), S. pyogenes ATCC $12344^{\mathrm{T}}$ (strain 5), S. agalactiae $\mathrm{NCTC} 8181^{\mathrm{T}}$ (strain 6), and E. coli $\mathrm{K}-12$ (strain 7).

The homology values calculated after $2 \mathrm{~h}$ of hybridization were not significantly different from the values calculated after $24 \mathrm{~h}$ of hybridization, even though the extent of hybridization was only $20 \%$ of that obtained after $24 \mathrm{~h}$ (Fig. 6 ). Thus, we used 2-h hybridization times for determinations of genetic relatedness among bacterial strains and for identification of bacteria. Another reason that we selected the 2-h

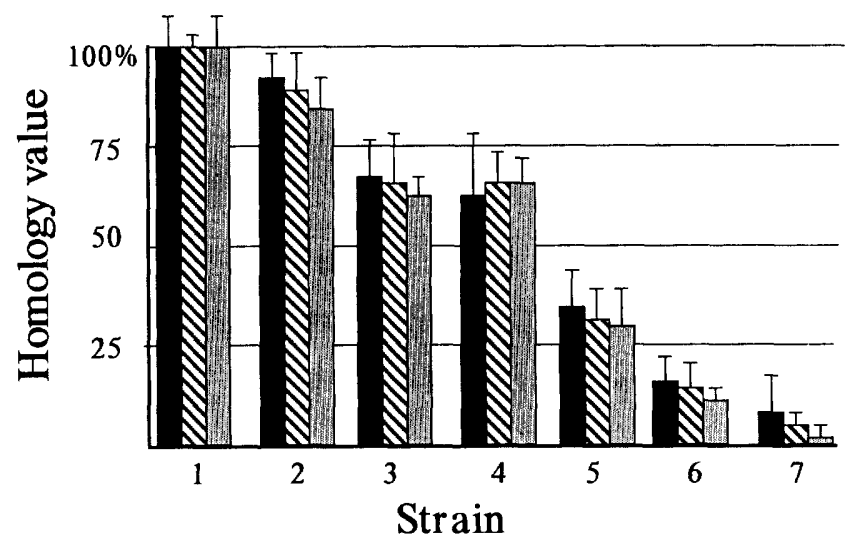

FIG. 7. Fluorometric direct binding method compared with two membrane filter methods. The fluorometric direct binding method (shaded bars) was compared with a membrane filter method in which photobiotin was used (cross-hatched bars) and with a radioisotope method (solid bars). S. anginosus NCTC $10713^{\mathrm{T}}$ was labeled, and each hybridization experiment was carried out at $37^{\circ} \mathrm{C}$ in $2 \times \mathrm{SSC}$ containing $50 \%$ formamide. The hybridization time for the fluorometric direct binding method and the photobiotin method was $2 \mathrm{~h}$, and the hybridization time for the radioisotope method was overnight. The bars at the tops of the columns indicate standard deviations. The average homology values were determined after six experiments. Unlabeled competitive DNAs were from $S$. anginos $u s$ NCTC $10713^{T}$ (strain 1), S. anginosus GIFU 10035 (strain 2). S. anginosus ATCC 27335 (strain 3), S. anginosus ATCC 27823 (strain 4), S. pyogenes ATCC $12344^{\mathrm{T}}$ (strain 5), $S$, agalactice NCTC $8181^{\mathrm{T}}$ (strain 6), and E. coli $\mathrm{K}-12$ (strain 7).
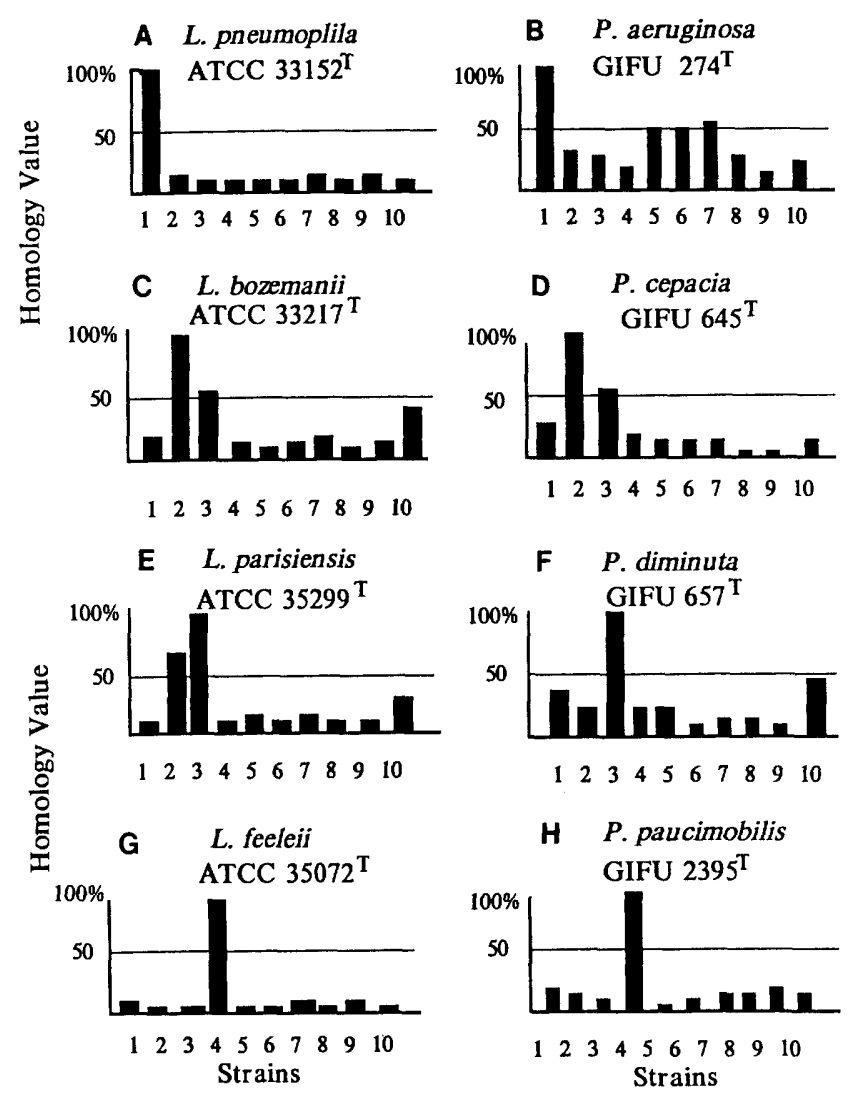

FIG. 8. Identification of legionellae and pseudomonads. Unlabeled single-stranded DNAs from 10 type strains of Legionella spp. and 10 type strains of Pseudomonas spp. were immobilized in microdilution wells. A 50-ng portion of labeled, single-stranded DNA from each type strain was distributed to a well. Hybridization was carried out at $45^{\circ} \mathrm{C}$ for legionellae and at $50^{\circ} \mathrm{C}$ for pseudomonads for $2 \mathrm{~h}$ in $2 \times$ SSC hybridization mixture containing $50 \%$ formamide. The enzyme reaction for beta-D-galactosidase was stopped within 30 min after the substrate, 4-methylumbelliferyl-beta-D-galactopyranoside, was added. The names of the organisms on the graphs indicate the labeled strains. (A. C, E, and G) Unlabeled competitive DNAs were from $L$. pneumophila ATCC $33152^{\mathrm{T}}$ (strain 1), L. bozemanii ATCC $33217^{\mathrm{T}}$ (strain 2), L. parisiensis ATCC $35299^{\mathrm{T}}$ (strain 3), L. feeleii ATCC $35072^{\mathrm{T}}$ (strain 4), L. rublilucens ATCC $35304^{\mathrm{T}}$ (strain 5), L. erythra ATCC $35303^{\mathrm{T}}$ (strain 6), L. cherii ATCC $35252^{\mathrm{T}}$ (strain 7), L. jamestownensis ATCC $35298^{\mathrm{T}}$ (strain 8), L. micdadei ATCC $33218^{\mathrm{T}}$ (strain 9), and L. gormanii ATCC $33297^{\mathrm{T}}$ (strain 10). (B, D, $\mathrm{F}$, and $\mathrm{H}$ ) Unlabeled competitive DNAs were from $P$. aeruginosa GIFU $274^{\mathrm{T}}$ (strain 1), $P$. cepacia GIFU $645^{\mathrm{T}}$ (strain 2 ), $P$. diminuta GIFU $657^{\mathrm{T}}$ (strain 3), P. paucimobilis GIFU $2395^{\mathrm{T}}$ (strain 4), $P$. pseudoalcaligenes GIFU $363^{\mathrm{T}}$ (strain 5), P. mendocina GIFU $1953^{\mathrm{T}}$ (strain 6), $P$. stutzeri GIFU $404^{\mathrm{T}}$ (strain 7), P. putida GIFU $1081^{\mathrm{T}}$ (strain 8), P. fluorescens ATCC $13523^{\mathrm{T}}$ (strain 9), and $P$. vesicularis GIFU $2388^{\mathrm{T}}$ (strain 10).

hybridization times is that sometimes when the 24-h times were used, the fluorescence intensity reached the maximum level within a few minutes after the 4-methylumbelliferylbeta-D-galactopyranoside was added, so that the relative homology values among the test strains could not be calculated. On the other hand, when 2-h hybridization times were used, it always took 15 to $60 \mathrm{~min}$ to reach the maximum intensity that could be read by the Microfluor fluorescence reader.

Hybridization in microdilution wells has several advantages. It is possible to automate the procedure, and the 
microdilution plates on which reference DNAs are fixed can be stored in a desiccator at room temperature.

DNA labeling with photobiotin is simpler than enzymatic labeling methods, such as nick translation (18) or random primed DNA labeling (11). Membrane filter hybridization in which photobiotin is used requires extensive washing; fluorometric direct binding in microdilution wells requires less washing.

We prepare microdilution plates in which reference DNAs of medically important bacteria are fixed, and the plates are stored under dry conditions (8). When an unknown organism is isolated, its DNA is extracted from 1 to $3 \mathrm{ml}$ of an overnight culture broth by using a small-scale DNA extraction method (15). The DNA is then labeled with photobiotin, and hybridization is carried out to identify the most closely related organism among the organisms whose reference DNAs are fixed in microdilution wells. This method is used successfully for identification of clinically important human bacteria. In many cases, it is not possible to estimate the exact $\mathrm{G}+\mathrm{C}$ content of the DNA of a new isolate before hybridization. Thus, we prepare two hybridization temperatures, 45 and $50^{\circ} \mathrm{C}$. When an isolate is thought to be a vibrio, campylobacter, bacteroides, legionella, streptococcus, staphylococcus, or anaerobic coccus, $45^{\circ} \mathrm{C}$ is selected for the hybridization temperature because these organisms have DNA $\mathrm{G}+\mathrm{C}$ contents that are less than $50 \mathrm{~mol} \%$. Hybridization at $50^{\circ} \mathrm{C}$ is used for identification of pseudomonads and micrococci, which have $\mathrm{G}+\mathrm{C}$ contents greater than $60 \mathrm{~mol} \%$.

\section{LITERATURE CITED}

1. Bolton, E. T., and B. J. McCarthy. 1962. A general method for the isolation of RNA complementary to DNA. Proc. Natl. Acad. Sci. USA 48:1390-1397.

2. Brenner, D. J., G. R. Fanning, A. V. Rake, and K. E. Johnson. 1969. Batch procedure for thermal elution of DNA from hydroxyapatite. Anal. Biochem. 28:447-459.

3. Coykendall, A., P. M. Wesbecher, and K. B. Gustafson. 1987. "Streptococcus milleri," Streptococcus constellatus, and Streptococcus intermedius are later synonyms of Streptococcus anginosus. Int. J. Syst. Bacteriol. 37:222-228.

4. Crosa, J. H., D. J. Brenner, and S. Falkow. 1973. Use of a single-strand-specific nuclease for analysis of bacterial and plasmid deoxyribonucleic acid homo- and heteroduplexs. J. Bacteriol 115:904-911.

5. De Ley, J., H. Cattoir, and A. Reynaerts. 1970. The quantitative measurement of DNA hybridization from renaturation rates. Eur. J. Biochem. 12:133-142.

6. Ezaki, T., Y. Hashimoto, N. Takeuchi, H. Miura, Y. Matsuì, and E. Yabuuchi. 1988. Simple genetic identification method of viridans group streptococci by colorimetric dot hybridization and quantitative fluorometric hybridization in microdilution wells. J. Clin. Microbiol. 26:1708-1713.

7. Ezaki, T., N. Takeuchi, S. L. Liu, A. Kai, H. Yamamoto, and E. Yabuuchi. 1988. Small-scale DNA preparation for rapid genetic identification of Campylobacter species without radioisotope. Microbiol. Immunol. 32:141-150.

8. Ezaki, T., N. Yamamoto, K. Ninomiya, S. Suzuki, and E. Yabuuchi. 1983. Transfer of Peptococcus indolicus, Peptococcus asaccharolyticus, Peptococcus prevotii, and Peptococcus magnus to the genus Peptostreptococcus and proposal of Peptostreptococcus tetradius sp. nov. Int. J. Syst. Bacteriol. 33: 683-698.

9. Fineberg, A. P., and B. Vogelstein. 1983. A technique for radiolabeling DNA restriction endonuclease fragments to high specific activity. Anal. Biochem. 132:6-13.

10. Forster, A. C., J. L. McInnes, D. C. Skingle, and R. H. Symons. 1985. Non-radioactive hybridization probes prepared by chemical labelling of DNA and RNA with a novel reagent, photobiotin. Nucleic Acids Res. 3:745-761.

11. Gebeyechu, G., P. Y. Rao, P. SooChan, D. A. Simms, and L. Klevan. 1987. Novel biotinylated nucleotide-analogs for labeling and colorimetric detection of DNA. Nucleic Acids Res. 15:4513-4534.

12. Gillespie, D., and S. Spiegelman. 1965. A quantitative assay for DNA/RNA hybrids with DNA immobilized on a membrane. J. Mol. Biol. 12:829-842.

13. Johnson, J. L. 1984. Nucleic acids in bacterial classification, p. 8-11. In N. R. Krieg and J. G. Holt (ed.), Bergey's manual of systematic bacteriology, vol. 1. The Williams \& Wilkins Co., Baltimore.

14. Leary, J. J., D. J. Brigati, and D. C. Ward. 1983. Rapid and sensitive colorimetric method for visualizing biotin-labeled DNA probes hybridized to DNA or RNA immobilized on nitrocellulose:bio-blots. Proc. Natl. Acad. Sci. USA 80:40454049.

15. Meinkoth, J., and G. Wahl. 1984. Hybridization of nucleic acids immobilized on solid supports. Anal. Chem. 138:267-284.

16. Neurath, A. R., and N. Strick. 1981. Enzyme-linked fluorescence immunoassays using $\beta$-galactosidase and antibodies covalently bound to polystyrene plates. J. Virol. Methods 3: $155-165$.

17. Renz, M., and C. Kurz. 1984. A colorimetric method for DNA hybridization. Nucleic Acids Res. 12:3435-3444.

18. Rigby, P. W., M. Dickmann, C. Rhodes, and P. Berg. 1977. Labeling deoxyribonucleic acid to high specific activity in vitro by nick translation with DNA polymerase I. J. Mol. Biol. 113:237-251.

19. Seidler, R. J., and M. Mandel. 1972. Quantitative aspects of deoxyribonucleic acid renaturation: base composition, state of chromosome replication, and polynucleotide homologies. J. Bacteriol. 106:608-614.

20. Yokota, Y., K. Yokoo, and Y. Nagata. 1986. A quantitative assay for the detection of hepatitis B virus DNA employing a biotinlabeled DNA probe and the avidin- $\beta$-galactosidase complex. Biochim. Biophys. Acta 868:45-50. 